\title{
Sociálny kapitál a subjektívna pohoda na Slovensku ${ }^{1}$
}

Marianna Mrva ${ }^{2}$

Sociologický ústav Slovenskej akadémie vied, Bratislava



Social Capital and Subjective Well-Being in Slovakia. This paper explores the link between social capital and subjective well-being in Slovakia using data from the last four waves of the European Values Survey. The results of the multiple linear regression analysis highlight that the only statistically significant predictors through all four waves of the study are household income and trust in institutions. These findings demonstrate that our wellbeing is determined not only by our direct circumstances but also by our perception of our institutional environment.

Sociológia 2020, Vol. 52 (No. 2: 111-131)

https://doi.org/10.31577/sociologia.2020.52.2.5

Key words: Subjective well-being; life satisfaction; social capital; trust; institutional trust

\section{Úvod}

Osobná pohoda (anglicky well-being) je koncept, ktorý je súčast'ou uvažovania o spoločnosti už od čias Aristotela, avšak do popredia záujmu spoločenskovedného výskumu sa dostal až v posledných dekádach. V súčasnosti sme svedkami postupného prenikania problematiky osobnej pohody zo sféry filozofie a sociálnych vied do sféry politiky, kde sa popri ekonomických ukazovatel'och stáva jedným $\mathrm{z}$ indikátorov úrovne kvality života $\mathrm{v}$ spoločnosti. Takýto prístup podporuje aj OSN, ktorá každoročne vydáva tzv. Svetovú správu o št'astí, ktorej súčast'ou je poradie krajín od najviac k najmenej št'astným. Podl'a správy z roku 2020 najšt'astnejšími krajinami sveta sú škandinávske krajiny na čele s Fínskom, Slovensko v tomto rebríčku obsadilo 37. miesto (Helliwell et al. 2020). Okrem stanovenia poradia krajín Svetová správa o št’astí poukazuje na niekol'ko d'alších zaujímavých skutočností, napríklad na dôležitost' podpory zo strany rodiny a komunity, predpokladaného veku dožitia v zdraví, slobody rozhodovania o vlastnom živote a pod., ktoré podobne ako materiálny blahobyt (v tomto prípade HDP na obyvatel'a) formujú výrazným spôsobom to, ako l'udia vnímajú svoj vlastný život.

Na skutočnost', že hoci v bohatších krajinách je väčšia aj pohoda (wellbeing) obyvatel'stva, vzt'ah osobnej pohody a materiálneho blahobytu nie je priamy a ani automatický, upozorňujú aj iné výskumy (pozri napr. Easterlin et al. 2010).

\footnotetext{
1 Štúdia je výstupom projektu APVV-15-0653 Hodnoty v dynamike spoločenských zmien na Slovensku a v Európe (HODYSE) a projektu VEGA 2/0122/19 Spoločenská dôvera na Slovensku.

${ }^{2}$ Korešpondencia: Mgr. Marianna Mrva, Sociologický ústav Slovenskej akadémie vied, Klemensova 19, 81364 Bratislava, Slovenská republika. E-mail: marianna.mrva@savba.sk
} 
Bádatelia rozlišujú objektívnu a subjektívnu pohodu. Objektívna pohoda sa vzt’ahuje na objektívne pozorovatel'né a meratel'né skutočnosti, ako napríklad materiálne podmienky života, hmotné statky alebo zdravotný stav, zatial' čo subjektívna pohoda vyjadruje vnútorné, kognitívne a afektívne prežívanie a hodnotenie reality vlastného života (Easterlin 2001; Diener et al. 2009). V tejto štúdii sa budem venovat' práve tejto subjektívnej osobnej pohode a sociálnemu kapitálu ako jej determinantu. Výskumnou otázkou je, do akej miery ovplyvňuje sociálny kapitál subjektívnu pohodu na Slovensku. Ako východisko mi budú slúžit' dáta z Výskumu európskych hodnôt (EVS), ktoré umožňujú sledovat' vývoj subjektívnej pohody na Slovensku v štyroch vlnách výskumu realizovaných v rokoch 1991, 1999, 2008 a 2017.

\section{Epistemologické otázky skúmania subjektívnej pohody}

Ako opisujú Diener et al. (2009), empirické skúmanie subjektívnej pohody sa datuje na začiatok dvadsiateho storočia. Veenhoven (2008) však poznamenáva, že téma subjektívnej pohody neabsentovala $\mathrm{v}$ sociológii ani predtým spokojnost' s prácou je dlhodobo témou sociológie práce, podobne ako je spokojnost's rodinným životom témou sociológie rodiny alebo spokojnost' so životom témou sociológie starnutia.

Podl'a Veenhovena však pri skúmaní subjektívnej pohody musíme čelit' niekol'kým epistemologickým problémom. Prvým z nich je, čo subjektívna pohoda znamená a ako ju môžeme odlíšit' od jej determinantov. V súvislosti s touto otázkou Veenhoven hovorí, že sociológovia obvykle neskúmajú len to, ako sa niekto cíti, ale ako sa niekto cíti v súvislosti s niečím a prečo. Subjektívna pohoda je však výsledkom celkového hodnotenia života, ktoré berie do úvahy aj jej pozitívne, aj jej negatívne stránky (Diener et al. 1997), a teda nie je obmedzená na konkrétne pocity v súvislosti s konkrétnymi stránkami života.

Druhá otázka, ktorú si podl'a Veenhovena musíme položit', je, ako posudzujeme našu subjektívnu pohodu. Na túto otázku existuje niekol'ko pohl'adov. Podl'a teórie sociálneho konštruktivizmu naša subjektívna pohoda závisí od zdiel'aných predstáv o živote $\mathrm{v}$ spoločnosti, ktoré následne formujú hodnotenie vlastného života zo strany jednotlivcov. Podl'a tohto prístupu subjektívna pohoda taktiež závisí od danej kultúry. Veenhoven však hovorí, že empirické dáta ukazujú vel'kú zhodu v determinantoch subjektívnej pohody bez ohl'adu na kultúrne rozdiely (Veenhoven - Kalmijn 2005). Iný pohl'ad na posudzovanie subjektívnej pohody poskytuje teória sociálneho porovnávania, ktorá hovorí, že subjektívna pohoda je rozdiel medzi tým, aký život je a aký by mal byt'. Čím menší je tento rozdiel, tým väčšia je subjektívna pohoda. Toto potvrdzuje podl'a Veenhovena aj Easterlinovo (1974) zistenie, že hospodársky rast neznamená automaticky rast subjektívnej pohody obyvatel'stva. Avšak, ako hovorí Veenhoven, porovnávat's ostatnými môžeme iba viditel'né aspekty 
nášho života, ako napríklad náš príjem, mnohé aspekty, ktoré prispievajú k našej subjektívnej pohode, však porovnatel'né s inými nie sú.

Tretí epistemologický problém, ktorému musíme čelit', je podl'a Veenhovena otázka, aké podmienky podporujú subjektívnu pohodu. Na makroúrovni výskumy väčšinou pracujú s takými charakteristikami spoločnosti, ako napríklad stupeň modernizácie a individualizácie, sociálne istoty a spoločenské nerovnosti. Na úrovni jednotlivých spoločností s charakteristikami, ako napríklad sociálne postavenie, spoločenská participácia, siet' spoločenských vzt’ahov jednotlivcov a pod.

Štvrtá a posledná otázka, ktorú si podl’a Veenhovena musíme položit', znie: aké sú následky nízkej alebo vysokej subjektívnej pohody? Pri odpovedi sa odvoláva na prehl'ad literatúry, ktorý uskutočnili Lyubomersky, King a Diener (2005) a ktorý poukazuje na pozitívny vplyv subjektívnej pohody na rôzne aspekty života, napríklad na kreativitu, spoločenské kontakty, pracovný výkon a fyzické zdravie.

V tejto štúdii sa budem venovat' najmä tretej otázke, ktorú položil Veenhoven, a to determinantom subjektívnej pohody, avšak predtým je potrebné tento jav zadefinovat'.

Ako poznamenáva Maddux (2018), môžeme rozlíšit' dve základné konceptualizácie subjektívnej pohody, a to hedonistické a eudaimonistické koncepty. Hedonistické koncepty definujú subjektívnu pohodu pomerom prijemných a nepríjemných udalostí v živote (Haybron 2008). Dobrý život je podl'a tohto prístupu život, v ktorom je viac pôžitku a radosti ako bolesti a utrpenia, bez ohladu na pôvod týchto pocitov. Zástancom takejto konceptualizácie je aj Ed Diener, jeden z najvplyvnejších autorov v oblasti subjektívnej pohody. Diener hovorí, že vysoká subjektívna pohoda charakterizuje l'udí, ktorí sú spokojní so životom a často pocit'ujú radost' a iba zriedkavo negatívne emócie ako smútok alebo hnev. Naopak, nízka subjektívna pohoda je typická pre l'udí, ktorí sú nespokojní so svojím životom, negatívne emócie pocitujú často a pozitívne zriedkavo (Diener et al. 1997: 25).

Eudaimonické konceptualizácie, ktorých názov odkazuje na Aristotela, vychádzajú z predstavy, že l'udia prosperujú, ak využívajú svoje l'udské kapacity naplno (Haybron 2008). Podl'a tohto prístupu teda subjektívna pohoda nie je prejavom prežívaných emócií a spokojnosti, ale odzrkadlluje to, do akej miery využíva niekto svoj potenciál (Maddux 2018).

\section{Meranie subjektívnej pohody}

Dolan, Kudrna a Testoni (2017) píšu, že stupeň subjektívnej pohody jednotlivcov môže spoluvytvárat' v podstate všetko, čo zažívajú a cítia, od podmienok, v ktorých žijú, cez aktivity, do ktorých sa zapájajú, až po ich myšlienky a vnútorné pocity. Napriek tomu subjektívna pohoda sa často meria prostredníctvom 
jednej otázky. Je to preto, že jednotlivé determinanty subjektívnej pohody môžu mat' rôzny vplyv na jej výslednú podobu - v živote rôznych l'udí môžu mat' rôznu váhu.

Ako opisujú Diener et al. (2009) výskumníci začali zarad'ovat' do svojich výskumov otázky o št’astí a spokojnosti so životom na začiatku dvadsiateho storočia. Prvé meracie nástroje často pozostávali iba z jedinej otázky, ktorá merala št’astie alebo spokojnost' pomocou krátkej škály, časom sa však postupne rozšíril tak rozsah otázok, ako aj ich škály. Dlho však ostala nezodpovedanou otázka, či sú sebazarad’ovacie škály vhodné na meranie takého konštruktu, akým je subjektívna pohoda (Diener et al. 2009). Ako uvádzajú Helliwell a Putnam (2004), bádatel'om sa v posledných rokoch podarilo dokázat', že osobná pohoda sa dá dostatočne spol'ahlivo merat' pomocou sebazarad'ovacích škál št'astia a spokojnosti so životom. Dokonca mnohé medzinárodné komparatívne výskumy dlhodobo pracujú iba s vel'mi obmedzenou batériou otázok. Vo Výskume európskych hodnôt subjektívne vnímanie života vo všeobecnosti skúmajú dve otázky - jedna zameraná na spokojnost' so životom, druhá na pocit štastia.

Niektorí bádatelia medzi týmito dvoma pojmami ani nerozlišujú. Napríklad Veenhoven (1991), jeden z najvplyvnejších výskumníkov št’astia a zostavovatel' databázy výskumov št’astia, uvádza, že ,spokojnost' so životom je chápaná ako miera, do akej považuje jednotlivec kvalitu svojho života vcelku za priaznivú. Inými slovami: ako vel'mi sa mu páči život, ktorý vedie. Termín št’astie sa bude používat' ako synonymum“ (s. 17). Mastekaasa a Moum (1984) uvádzajú: „Kvalitu života definujeme ako jednodimenzionálny jav súvisiaci s náladou a náklonnost'ou (,„st'astie“ alebo „spokojnost"“)“ (s. 392). Lane (2000) sa na teoretickej úrovni síce snaží rozlišovat medzi týmito javmi, no takéto rozlíšenie vo svojich výskumoch reálne nepoužíva. Všetci menovaní autori jednoducho predpokladajú, že št'astie a spokojnost' sa dajú považovat' za synonymá, alebo že z analytického hl'adiska nie je potrebné medzi nimi rozlišovat'. Osobnú pohodu teda považujú za všeobecnejší pojem, ktorého súčastou - často synonymicky chápanou - je tak pocit osobného št'astia, ako aj spokojnosti.

$\mathrm{V}$ iných prípadoch však autori zdôrazňujú jeden $\mathrm{z}$ týchto konceptov. Campbell a kol. (1976) napríklad tvrdia, že spokojnost' je vhodnejším pojmom, pretože „spokojnost' je úsudok alebo kognitívna skúsenost', zatial' čo št'astie naznačuje zážitok alebo pocit náklonnosti““ (s. 8). Podobne Lane (2000) tvrdí, že ,št'astie je nálada, spokojnost' so životom je viac kognitívny úsudok“ (s. 275). Podl'a Campbella a kol. (1976) spokojnost' možno „definovat' ako vnímaný rozdiel medzi ašpiráciou a dosiahnutým výsledkom“ (s. 8).

Ako uvádzajú Helliwell a Putnam (2004), empirické výskumy dokazujú, že kým otázka skúmajúca sebazarad’ovanie na škále št’astia reflektuje krátkodobejšiu, situačne podmienenú náladu, sebazarad'ovanie na škále spokojnosti 
so životom indikuje dlhodobejší, stabilnejší stav. S týmito zisteniami korešponduje aj ich analýza dát z Výskumu svetových hodnôt, ktorá naznačuje, že odpovede na otázku o spokojnosti so životom vypovedajú viac o životných skúsenostiach ako o aktuálnych podmienkach alebo nálade. Ich záver teda znie, že je relevantnejšie skúmat' širší spoločenský kontext práve vo vzt'ahu k spokojnosti so životom, ked’že $\mathrm{v}$ porovnaní so št'astím ide o stabilnejší koncept. Vychádzajúc z týchto skúseností, budem v tomto článku subjektívnu pohodu merat' pomocou otázky zist'ujúcej spokojnost' so životom, aj ked' v našom výskume spokojnost' a št'astie spolu stredne až silne korelujú: hodnota Spearmanovho rho koeficientu sa pohybuje od $0,432 \mathrm{v}$ roku 1991 až po $0,560 \mathrm{v}$ roku 2008.

Spokojnost' so životom bola v EVS meraná otázkou: Ked' zoberiete do úvahy všetky okolnosti, ako ste v súčasnosti spokojný so svojím životom? Respondenti mohli odpovedat' na desat'stupňovej škále od nespokojný (1) po spokojný (10). Z výsledkov EVS vyplýva, že v každej vlne výskumu bola väčšina l'udí skôr spokojná. V roku 1991 priemerná hodnota spokojnosti bola na desat'stupňovej škále 6,8, potom nastal v roku 1999 mierny pokles na 6,0, avšak v roku 2008 už môžeme pozorovat' jej nárast na 7,2 a v roku 2017 d'alší mierny nárast na 7,3.

\section{Determinanty subjektívnej pohody}

$\mathrm{Z}$ determinantov subjektívnej pohody boli dlhodobo $\mathrm{v}$ centre pozornosti sociálnych výskumov prevažne individuálne faktory. Poukazovali na to, že psychologické faktory, ako napríklad optimizmus a sebavedomie, hrajú dôležitú úlohu, ale okrem nich majú vel'ký vplyv na subjektívnu pohodu aj zdravotný stav, rodinný status, vzdelanie, postavenie v zamestnaní a vek (Helliwell 2002). Vzt'ah medzi príjmom a pohodou patrí tiež medzi často skúmané oblasti, najmä vd’aka priekopníckym výskumom Richarda Easterlina, ktorý poukázal na to, že l'udia s vyšším príjmom sa v priemere môžu tešit' väčšej pohode, avšak priemerná úroveň osobnej pohody obyvatel'ov sa so zvyšovaním bohatstva ich krajiny nezvyšuje. Tento jav sa nazýva Easterlinovým paradoxom a najčastejšie sa vysvetl'uje dôležitost'ou relatívneho príjmu a rastúcich ašpirácií spolu s porovnávaním sa rôznych spoločenských skupín medzi sebou (Portela et al. 2013). Easterlinov výskum a jemu podobné výskumy poukázali na dôležitost' rozšírenia skúmania individuálnych determinantov osobnej pohody na širšie spoločenské súvislosti. $Z$ nich je azda najdôležitejší sociálny kapitál, ktorého súvislost' so subjektívnou pohodou sa skúma tak na mikro-, ako aj na makroúrovni (pozri napr. Bjørnskov 2003, 2008; Sarracino 2010). Bartolini et al. (2008) pri skúmaní tohto vzt’ahu došli k záveru, že v USA práve pokles sociálneho kapitálu (v jeho analytickom chápaní) spôsobil Easterlinov paradox tým, že prevážil nad rastom príjmov. Podl’a autorov teda rast príjmov spôsobuje 
zvyšovanie osobnej pohody iba vtedy, ked' zároveň neklesá úroveň sociálneho kapitálu, teda ich stav a vývoj sú konzistentné. Sarracino (2010) prostredníctvom empirickej analýzy jedenástich západoeurópskych krajín zistil, že hoci zmeny sociálneho kapitálu v USA a v Európe nevykazujú rovnaký trend (v USA úroveň sociálneho kapitálu poklesla, kým vo väčšine sledovaných západoeurópskych krajín za posledných 20 rokov jeho úroveň narástla), sociálny kapitál je dôležitým vysvetlujúcim faktorom úrovne osobnej pohody aj v Európe.

\section{Sociálny kapitál}

Pojem sociálny kapitál použil ako prvý pravdepodobne Lyda Hanifan, inšpektor vidieckych škôl, ešte v roku 1916, ked’ sa vo svojom článku snažil zdôraznit' význam ústretovej a priatel'skej pospolitosti. Už v tom čase si Hanifan uvedomoval, že spojenie jedinca so skupinou zvýši jeho šance na uspokojenie svojich sociálnych potrieb. Pojem sa však v tom období ešte vo vede neudomácnil. Od 50. rokov dvadsiateho storočia sa začal spomínat' častejšie (Banfield 1967; Homans 1961; Jacobs 1961; Loury 1977), avšak výrazne ho spopularizovali až Pierre Bourdieu, James Coleman a Robert Putnam (Keller 2010). Význam sociálneho kapitálu sa však postupne menil.

Existujú dve najvplyvnejšie konceptualizácie pojmu sociálny kapitál:

1. Európske postštrukturalistické a individualistické chápanie, ktoré reprezentuje napríklad Pierre Bourdieu. Bourdieu definoval sociálny kapitál ako „siet(e) viac či menej inštitucionalizovaných vzt’ahov, ... ktoré poskytujú svojim členom podporu kolektívne vlastneného kapitálu“ (Bourdieu 1986: 248-249). Sociálny kapitál vníma ako reálne vlastníctvo súčtu skutočných a potenciálnych zdrojov vo vlastníctve relatívne pevných sietí viac alebo menej inštitucionalizovaných vzt’ahov vzájomnej známosti a uznania. Miera a hodnota sociálneho kapitálu závisí podl'a neho od rozsahu siete spojení, v ktorých sa daný jedinec môže efektívne mobilizovat', ako aj od vel'kosti nadobúdaného kapitálu (ekonomického, kultúrneho alebo symbolického) v rámci siete daných jedincov. $\mathrm{Z}$ toho vyplýva, že sociálny kapitál nie je nikdy úplne nezávislý od iného kapitálu, napríklad ekonomického alebo kultúrneho (Ruman 2013).

Bourdieuho koncept sociálneho kapitálu úzko súvisí aj s jeho konceptom „habitusu“, súhrnu potrieb a schopností, ktoré indivíduum získava v procese socializácie (Bourdieu 1977).

2. Konceptualizácia sociálneho kapitálu v analytickej, najmä americkej sociológii, ktorá vychádza z koncepcie l'udského kapitálu Theodora W. Schultza (1960) a Geryho Beckera (Becker 1962, 1964), amerických ekonómov, ktorí zavedením tohto pojmu pripravili cestu pre širšie pochopeonceptu „kapitálu“ (Ostron - Ahn 2009). Ludský kapitál v ich ponímaní tvoria všetky zdroje, vedomosti, zručnosti, skúsenosti, ktorými disponujú jednotlivci alebo skupiny. 
Tieto zdroje predstavujú formu bohatstva, ktorá môže byt' využitá na dosiahnutie ciel'ov národa alebo štátu (Lin 2007).

Prvú systematickú konceptualizáciu sociálneho kapitálu však vytvoril až James Coleman (1988). Coleman vychádzal z paradigmy racionálnej vol'by a rozmýšl'al o tomto jave ako o zdroji, ktorý sa dá využit' na maximalizáciu osobného profitu - podl’a neho sociálny kapitál je jeden z možných zdrojov, ktorý má aktér k dispozícii. Ako hovorí, podobne „ako iné formy kapitálu, sociálny kapitál je produktívny, umožňuje dosiahnut určité ciele, ktoré by nebolo možné dosiahnut' pri jeho absencii“" (Coleman 1988: 98). Zdôrazňuje, že existujúci sociálny kapitál nie je užitočný iba z hl'adiska jednotlivca sledujúceho svoj vlastný profit, ale má prínos aj pre ostatných, v niektorých prípadoch dokonca aj pre tých, ktorí nie sú členmi danej skupiny alebo siete (Keller 2010). Avšak uprednostňuje individuálne schopnosti jedinca, t. j. konanie a výber, na úkor komplexnejších princípov. Nezaprie inšpiráciu teóriou racionálnej vol'by, v rámci ktorej povyšuje jednotlivca nad celok (Ruman 2013).

Jamesom Colemanom sa inšpiroval Robert Putnam, ktorý svojím článkom a neskôr knihou Bowling Alone (2001) generoval nevídaný záujem o koncept sociálneho kapitálu. Putnam na rozdiel od Colemana uvažoval o dôvere najmä $\mathrm{v}$ makrosociálnej rovine a definoval tento pojem ako „prepojenia medzi sociálnymi siet’ami jednotlivcov a normy reciprocity a dôvery, ktoré z nich vyplývajú“ (Putnam 2001: 16). Siete, normy a dôvera sú práve zložky, prostredníctvom ktorých sa od čias Putnama najčastejšie definuje sociálny kapitál (Portela et al. 2013).

Putnam taktiež ako prvý rozlíšil dva druhy sociálneho kapitálu: zväzujúci (bonding) a premost’ujúci (bridging) sociálny kapitál. Zväzujúci sociálny kapitál predstavujú podl'a neho blízke vzt’ahy, ktoré charakterizuje vysoká miera lojality, vzájomná dôvera a reciprocita. Premostujúci kapitál na druhej strane charakterizujú slabšie väzby, ktoré sa vytvárajú medzi členmi často vysoko diverzifikovaných skupín, ako sú napríklad rôzne vol’nočasové združenia, zamestnanecké kolektívy atd'. Podl’a Putnama zväzujúci sociálny kapitál pomáha pri napíňaní základných l'udských potrieb a premost'ujúci kapitál môže napomáhat' dosahovaniu ciel'ov a napredovaniu (Putnam 2001).

Podl'a Szretera a Woolcocka (2004) však Putnamove kategórie nezachytávajú statusové a mocenské rozdiely medzi skupinami, preto ich navrhli doplnit' o d’alší druh kapitálu - spájajúci (linking) sociálny kapitál. Kým premost’ujúci sociálny kapitál sa podla nich vzt'ahuje na horizontálne vzt’ahy medzi skupinami, ktoré majú približne rovnaký status, spájajúci sociálny kapitál sa objavuje vo vertikálnych vzt'ahoch, ktoré sú typické pre skupiny s rôznym statusom alebo vplyvom. Spájajúci sociálny kapitál sa preto dá vyjadrit' ako dôvera v autority (Szreter - Woolcock 2004). Uvažovanie o sociálnom kapitáli teda v súčasnosti rozlišuje tri typy spoločenských vzt’ahov. Zväzujúci sociálny 
kapitál sa odvíja od vzt'ahov charakteristických pre malé, do vnútra orientované, vysoko homogénne skupiny. Premost'ujúci kapitál vychádza zo vzt'ahov, ktoré spájajú ludí z rôznych, avšak statusovo a mocensky podobných skupín. Spájajúci sociálny kapitál sa týka nevyvážených, asymetrických vzt’ahov, kde je jedna zo strán zat’ažená väčšou mierou povinností a druhá väčšími právomocami. Spájajúci sociálny kapitál hovorí o miere, do akej sú l'udia ochotní dôverovat' vyššie postaveným a podporovat' formálne autority (Elgar et al. 2011).

Pri uvažovaní o sociálnom kapitály nemôžeme zabudnút' ani na to, že čoraz väčšia čast' našich životov sa odohráva $\mathrm{v}$ online prostredí, kde sa, podobne ako v offline svete, môže vytvárat' sociálny kapitál. Premost’ujúci sociálny kapitál sa môže vytvárat' napríklad na rôznych fórach, diskusných alebo svojpomocných skupinách. Ich participanti, ktorých spája záujem o danú tému, môžu pochádzat' $\mathrm{z}$ rôznych spoločenských skupín a z rôznych kútov sveta a mimo online prostredia sa nemusia navzájom poznat'. Na druhej strane, online môžeme posilnit' aj náš zväzujúci sociálny kapitál, napríklad prostredníctvom online komunikácie s rodinnými príslušníkmi či kamarátmi, s ktorými by sme bez internetu mohli stratit' kontakt (Norris 2002).

Vel'ký záujem o tému sociálneho kapitálu, ktorý môžeme pozorovat' v poslednom období (Isham et al. 2002), však niektorí autori vnímajú kriticky. Jan Keller napríklad hovorí, že sociálny kapitál je klasickým príkladom módneho pojmu, ktorý sa má dat' použit' na všetkých úrovniach analýzy a má umožnit' empiricky testovat' vzt'ahy medzi mierou integrity spoločnosti, jej ekonomickou výkonnost'ou, pocitom št’astia jej členov, úrovni dôvery v spoločnosti atd'. Podl'a neho toto všetko sú legitímne témy, avšak nie je vecný dôvod ich označovat’ nálepkou „,sociálny kapitál“ (Keller 2010).

\section{Indikátory sociálneho kapitálu}

Teoretické vymedzenia konceptu sociálneho kapitálu predstavujú často vel'mi široko koncipované konštrukty, ktorých operacionalizácia pre potreby empirického výskumu nie je jednoduchá úloha. Van Oorschoot a Arts (2005) však poznamenávajú, že existuje rastúci konsenzus $\mathrm{v}$ tom, že empirické indikátory sociálneho kapitálu sa dajú zoskupit' do troch široko chápaných dimenzií, ktoré vychádzajú zo spomínaných definícií sociálneho kapitálu. Tieto dimenzie sú: 1. sociálne siete (napríklad neformálne vzt’ahy, dobrovol'níctvo, členstvo v združeniach); 2. sociálne normy (napríklad spoločné normy a občianske hodnoty); 3. dôvera (medzil’udská, všeobecná a inštitucionalizovaná dôvera). Z tohto rozdelenia vychádzajú pri operacionalizácii sociálneho kapitálu van Oorschoot a Arts (2005), ktorí pri analýze dát z Výskumu európskych hodnôt zaradili medzi indikátory dimenzie sociálnych sietí členstvo v dobrovol'níckych združeniach, udržiavanie neformálnych kontaktov s rodinnými príslušníkmi a známymi a politickú angažovanost'. Medzi indikátory dôvery zaradili generalizo- 
vanú dôveru a dôveru $\mathrm{v}$ inštitúcie a medzi indikátory sociálnych noriem ospravedlnitel'nost' rôznych druhov konaní. Podobne postupovali pri analýze dát z Európskej sociálnej sondy aj Portela et al. (2013), avšak za indikátory dimenzie sociálnych noriem považovali aj rôzne formy politického konania, ako napríklad podpisovanie petícií, účast' na demonštráciách a zapojenie do bojkotu. Dáta z Európskej sociálnej sondy im taktiež umožnili pridat' do dimenzie sociálnych sietí okrem indikátorov bezprostredných vzt'ahov s najbližšími aj virtuálne a podporné siete.

Iní autori sa však pri operacionalizácii sociálneho kapitálu namiesto jeho dimenzií sústredili na jeho druhy, vymedzené napríklad Putnamom (2011) alebo Szreterom a Woolcockom (2004). Napríklad Elgar et al. (2011) pri analýze dát z Výskumu svetových hodnôt vychádzali z troch typov sociálneho kapitálu vymedzených Szreterom a Woolcockom (2004). Za indikátory zväzujúceho sociálneho kapitálu označili položky skúmajúce partikulárnu dôveru k blízkym l'ud’om, ako sú členovia rodiny, susedia a l'udia, ktorých respondent pozná osobne. Medzi indikátory zväzujúceho sociálneho kapitálu d’alej zaradili členstvo v združeniach. Premost’ujúci kapitál reprezentovali položky skúmajúce spoločenskú dôveru, spoločenský dištanc od rôznych skupín a taktiež občiansku zodpovednost'. Posledný typ, ktorým je spájajúci sociálny kapitál, reprezentovali vo výskume Elgara a kol. položky zamerané na skúmanie dôvery v inštitúcie a zapájania do politického života (Elgar et al. 2011). Podobné vymedzenie používal aj Helliwell (2002), ktorý podobne ako Elgar a kol. zaradil medzi indikátory sociálneho kapitálu spoločenskú zodpovednost', avšak použil iba jeden $\mathrm{z}$ jej indikátorov, a to vnímanie podvodov na daniach. Sarracino (2010) podobne ako citovaní autori analyzuje vzt'ah osobnej pohody a sociálneho kapitálu pomocou dát zo Svetového výskumu hodnôt, avšak sociálny kapitál chápe užšie a do svojej analýzy zahŕňa iba generalizovanú dôveru, dôveru v inštitúcie a participáciu v záujmových združeniach, ku ktorým pridáva ešte aj dobrovol’nícku prácu. Sarracino na rozdiel od Helliwella a Elgara a kol. (2011) rozlišuje medzi dvomi typmi záujmových združení. Do prvého typu zahŕňa organizácie, $\mathrm{v}$ ktorých je členstvo motivované vnútornými dôvodmi, ako napríklad členstvo $\mathrm{v}$ športových kluboch, mládežníckych organizáciách a pod. Túto skupinu združení nazýva Putnamovou skupinou, pretože vychádza z Putnamovho (1994) chápania združení ako spolkov založených na vzájomnej dôvere a reciprocite vzt'ahov. Do druhej skupiny Sarracino zahrnul organizácie, ktorých členmi sa l’udia stávajú na základe vonkajšej motivácie, z pragmatických dôvodov, lebo chcú prostredníctvom členstva za niečo lobovat', niečo dosiahnut'. Do tejto skupiny zaradil napríklad odbory, zamestnanecké organizácie, organizácie na ochranu spotrebitel'ov a pod. a nazval ju Olsonovou skupinou na základe definície Mancura Olsona (1982), ktorý zdô- 
razňoval tendenciu spolkov lobovat' za politické opatrenia sledujúce ich záujmy, hoci aj v neprospech spoločnosti ako celku (Sarracino 2010).

Z uvedených príkladov je zrejmé, že pri operacionalizácii sociálneho kapitálu sú výskumníci okrem teoretických vymedzení vedení najmä dostupnost'ou dát a skúmané indikátory prispôsobujú ich dostupnosti v databázach. Podobne je to aj $\mathrm{v}$ mojom prípade, ked’že ide o sekundárnu analýzu dát $\mathrm{z}$ Výskumu európskych hodnôt, pri vymedzení indikátorov budem vychádzat' z možností, ktoré poskytuje táto databáza. Ďalšia skutočnost', ktorú musím pri operacionalizácii brat' do úvahy, bude porovnatel'nost' štyroch vĺn tohto výskumu, čo ešte viac zužuje množstvo dostupných indikátorov. Napriek tomu sa domnievam, že všetky Putnamom (2001) definované dimenzie sociálneho kapitálu budú v mojom výskume dostatočne pokryté. Dáta z Výskumu európskych hodnôt využívajú na meranie sociálneho kapitálu mnohí výskumníci. Napríklad v databáze publikácií, ktoré pracujú s dátami EVS (EVS Bibliography 2020), sa nachádza viac ako 50 článkov, ktoré skúmajú sociálny kapitál pomocou EVS (medzi nimi napr. van Oorschot - Finsveen 2009; van Oorschot et al. 2006; Puntcher et al. 2014; Sarracino 2013; Sarracino - Mikucka 2016), a podobne to je aj vo Výskume svetových hodnôt (WVS publications 2020).

\section{Sociálny kapitál vo Výskume európskych hodnôt}

Pri operacionalizácii sociálneho kapitálu vo Výskume európskych hodnôt som vychádzala z dimenzií sociálneho kapitálu, ktorými sú sociálne siete, sociálne normy a dôvera. Dimenzia sociálnych sietí je vo výskume reprezentovaná indikátorom členstva $\mathrm{v}$ rôznych typoch dobrovol'ných združení, pričom respondenti mali možnost' odpovedat' aj ,iné“, ak sú členmi typu združenia, ktorý sa nenachádza v zozname. Výsledky analýzy tejto otázky poukazujú na masívny pokles členov združení medzi rokmi 1991 a 2008. Kým totiž vo vlnách 1991 a 1999 bol členom nejakého združenia každý druhý respondent, vo vlnách 2008 a 2017 už len každý štvrtý. Tento pokles je možné pozorovat' v každom type združenia, najviditel'nejší je však v prípade odborov (pokles z $21 \%$ v roku 1991 na 4,5 \% v roku 2017) a športových združení (pokles z 17,6 \% v roku 1999 na 7,2 \% v roku 2017). Je však potrebné poznamenat', že dotazník nezachytáva združovanie $\mathrm{v}$ online komunitách na internete, napríklad členstvo v rôznych svojpomocných skupinách, ktoré môžu byt' dôležitým zdrojom sociálneho kapitálu v dnešnom digitálnom svete (pozri napr. Drentea - MorenCross 2005; Wellman et al. 2001).

Z bloku otázok zameraného na členstvo $\mathrm{v}$ rôznych typoch organizácí́ som sa rozhodla vytvorit' binárny index, ktorý má hodnotu 0 (respondent nie je členom žiadneho združenia) alebo 1 (respondent je členom aspoň jedného združenia). 
Otázka zameraná na skúmanie vykonávania dobrovol’níckej práce bola zahrnutá do dotazníka až v roku 2017, preto som túto položku nemohla $\mathrm{v}$ analýze použit'.

Dimenzia sociálnych noriem bude v mojom výskume reprezentovaná indikátormi ospravedlnitel'nosti rôznych druhov konania, ktoré Elgar et al. (2011) nazvali občianskou zodpovednost'ou. Tento indikátor bol vo výskume meraný na desat'stupňovej škále od nikdy nemožno ospravedlnit' (1) až po vždy možno ospravedlnit' (10). V tejto oblasti budú predmetom mojej analýzy tri premenné: žiadanie o štátnu podporu, na ktorú človek nemá nárok, podvádzanie na daniach, ak je na to príležitost' a branie úplatku za splnenie svojich povinností. Odpovede respondentov na tieto otázky svedčia o tom, že väčšina l'udí odsudzuje takéto konanie a považuje ho za neospravedlnitel'né, avšak trend, ktorý možno vyčítat' $\mathrm{z}$ dát, hovorí o postupnom náraste akceptovania tohto konania, čo je najvýraznejšie $\mathrm{v}$ prípade neoprávnenej žiadosti o štátnu podporu. Priemerná hodnota tohto indexu bola v roku 1991 na desat'stupňovej škále 2,2, ale v roku 2017 už 3,4.

Analýza reliability ukázala, že vnútorná konzistencia škály zloženej z uvedených troch indikátorov občianskej zodpovednosti je dostatočne vysoká (Cronbachovo alfa má hodnotu 0,575 vo vlne 1991 až 0,833 vo vlne 2017), preto som sa rozhodla tieto premenné spojit' do jedného indexu.

Tretiu dimenziu, ktorú Putnam (2011) nazval oblast'ou dôvery, bude v mojej analýze reprezentovat' dôvera $\mathrm{k}$ l'ud'om vo všeobecnosti a dôvera $\mathrm{k}$ štátnym inštitúciám, ktoré vo výskume EVS reprezentujú armáda, školstvo, úrady, parlament, polícia, systém sociálneho zabezpečenia a súdy. V roku 2017 bol vo výskume prvýkrát zahrnutý aj blok otázok zameraný na partikulárnu dôveru, avšak pre ich neporovnatel'nost' $v$ čase som tieto otázky do výberu indikátorov nemohla zahrnút'.

Dôvera $\mathrm{k}$ štátnym inštitúciám bola vo výskume meraná na štvorstupňovej škále úplne dôverujem (1), skôr dôverujem (2), nie vel'mi dôverujem (3) a vôbec nedôverujem (4). V jej výsledkoch nastali za štyri vlny výskumu iba menšie zmeny, a teda $\mathrm{v}$ prípade štátnych inštitúcíi môžeme hovorit' skôr o stabilne nízkej dôvere.

V analýze som sa rozhodla škály dôvery k jednotlivým inštitúciám prekódovat' na dvojstupňovú škálu (nedôveruje (0) a dôveruje (1)) a následne z nich vytvorit' index dôvery $\mathrm{v}$ štátne inštitúcie, ktorý má rozptyl 0 (nedôveruje žiadnej inštitúcii) až 1 (dôveruje všetkým inštitúciám). Analýza reliability ukázala, že vnútorná konzistencia spájaných položiek je vysoká v každej vlne: Cronbachovo alfa má hodnotu 0,755 (vo vlne 1999) až 0,834 (vo vlne 2017). Priemerná hodnota tohto indexu sa pohybovala okolo hodnoty 2,4 až 2,5 .

Všeobecná (generalizovaná) dôvera bola v EVS meraná na binárnej škále väčsine l'udi možno dôverovat' (1) a opatrnosti v styku s inými l'ud’mi nikdy nie 
je nazvyš (2), ktorej výsledky za jednotlivé vlny výskumu majú tvar $\mathrm{U}-\mathrm{v}$ roku 1991 v l'udí vo všeobecnosti dôverovalo $21,0 \%$ opýtaných, avšak potom nastal pokles na úroveň $15,7 \% \mathrm{v}$ roku 1999 , respektíve $13,2 \% \mathrm{v}$ roku 2008 , po ktorom nasledoval nárast na $21,7 \%$ v roku 2017.

\title{
Tabul'ka č. 1: Vybrané indikátory sociálneho kapitálu v EV
}

\author{
Sociálne siete \\ Členstvo v dobrovol'ných organizáciách \\ Sociálne normy \\ Ospravedlnitel'nost' žiadania o štátnu podporu, na ktorú človek nemá nárok \\ Ospravedlnitel'nost' podvádzania na daniach, ak je na to príležitost' \\ Ospravedlnitel'nost' brania úplatku za splnenie svojich povinností \\ Dôvera \\ Generalizovaná dôvera \\ Dôvera k štátnym inštitúciám (armáda, školstvo, verejná správa a úrady, parlament, polícia, systém \\ sociálneho zabezpečenia, súdy a súdny systém)
}

\section{Kontrolné premenné}

Výskumy rôznych autorov poukazujú na dôležitost’ niektorých socioekonomických faktorov alebo skutočností pre subjektívnu pohodu. Vzt’ah medzi vekom a pohodou patrí medzi najširšie diskutované témy, najmä pre chýbajúci konsenzus. Wilson (1967) na základe štúdia literatúry tvrdil, že št’astní l'udia sú mladí l’udia, avšak neskôr jeho závery mnohí autori vyvrátili. Patria medzi nich napríklad Diener et al., ktorí na základe empirických výskumov tvrdili, že neexistuje jednoznačný vzt'ah medzi subjektívnou pohodou a vekom (Diener et al. 2009). Blanchflower a Oswald (2004) však identifikovali v dátach z USA a z Vel'kej Británie vzt'ah medzi spokojnost'ou so životom a vekom, ako aj št'astím a vekom v tvare $U$ - mladí boli najspokojnejší, avšak potom nastal zlom a spokojnost' začala klesat'. Štyridsat'roční respondenti boli najmenej spokojní so životom, vo vyššom veku začala spokojnost' znova narastat'. Podobný vzor opisuje vo svojej štúdii aj Helliwell (2002), ako aj Helliwell a Putnam (2004), ktorí však zdôrazňujú úlohu fyzického zdravia a hovoria, že vzt'ah medzi spokojnost'ou so životom a vekom opisuje tvar U iba v prípade, ak je brané do úvahy aj zdravie. V opačnom prípade najnižšia spokojnost' charakterizuje práve najstarších (Helliwell - Putnam 2004).

V prípade vzdelania mnohí poukazujú na jeho pozitínny vplyv na pohodu. Putnam (2000) napríklad hovorí, že vzdelanie je najsilnejší prediktor všetkých foriem participácie a participácia následne vedie $\mathrm{k}$ spokojnosti. V neskoršej empirickej štúdii s Helliwellom sa však už tento vzt’ah nepodarilo dokázat' a autori v nej hovoria len o nepriamom vplyve vzdelania na spokojnost' cez zdravie (Helliwell - Putnam 2004). 
Diener et al. (1999) vo svojom článku informujú, že viaceré štúdie potvrdzujú signifikantný vzt’ah medzi rodinným statusom a spokojnost'ou so životom. Podl'a týchto štúdií l'udia, ktorí žijú v manželskom zväzku, sú spokojnejší ako rozvedení, ovdovení alebo tí, ktorí nikdy nežili v manželstve. Hoci rodinné formy sa od uverejnenia článku Dienera a jeho spoluautorov stali ovel'a heterogénnejšími, o podobnej súvislosti medzi rodinným statusom a subjektívnou pohodou referujú aj niektoré novšie články (napr. Helliwell - Putnam 2004), iné však takýto vzt’ah jednoznačne nepotvrdzujú (napr. Shapiro - Keyes 2008).

Diskusii o vzt’ahu príjmu domácnosti a subjektívnej pohody som sa už čiastočne venovala $\mathrm{v}$ tomto texte. Aj vd’aka spomínanému Easterlinovmu paradoxu (pozri Smith 2014) sa vzt’ah príjmu a subjektívnej pohody v spoločenských vedách často skúma. Tieto výskumy väčšinou poukazujú na dve skutočnosti: 1) vzt'ah medzi príjmom a subjektívnou pohodou je väčšinou malý, 2) tento vzt'ah nie je lineárny - je silnejší v nižších príjmových skupinách a slabší vo vyšších príjmových skupinách (Luhmann et al. 2011). Na Slovensku skúmal vzt’ah medzi ekonomickými faktormi a psychologickou pohodou Želinský a kolektív (Želinský et al. 2018), ktorí dospeli k záveru, že výška príjmu a stabilná finančná situácia majú pozitívny vplyv na psychologickú pohodu.

Okrem týchto premenných býva $v$ literatúre často analyzovaný aj vzt'ah medzi zdravotným stavom a subjektívnou pohodou. Ngamba a kol. (Ngamaba et al. 2017) vo svojej metaanalýze 29 štúdií zistili, že zdravie má štatisticky signifikantne pozitívny vzt’ah so subjektívnou pohodou. Zdravotný stav však nebol súčast'ou dotazníka Výskumu európskych hodnôt vo všetkých štyroch sledovaných vlnách, preto tento prediktor nezodpovedal mojim kritériám a do analýzy som ho nemohla zahrnút'.

Do svojej analýzy som však zaradila okrem diskutovaných premenných aj pohlavie a vel'kost' sídla, a tak budem pracovat' s nasledujúcimi kontrolnými premennými: pohlavie, vek, najvyššie dosiahnuté vzdelanie, rodinný status, vel'kost' obce a príjem domácnosti.

\section{Analýza}

Na zodpovedanie výskumnej otázky, ako sociálny kapitál determinuje subjektívnu pohodu, použijem lineárnu regresiu, kde závislou premennou bude celková spokojnost' so životom, meraná na desat'stupňovej škále. Vychádzajúc z Normana (2010) a aj vzhl'adom na vel'kost' vzorky a rozloženie dát sa domnievam, že táto metóda je vhodná na analýzu týchto dát.

Nezávislými premennými budú už opísané indexy: členstvo v združení, dôvera $\mathrm{k}$ štátnym inštitúciám, ospravedlnitel'nost' konania, ako i premenná spoločenská dôvera. Z kontrolných premenných som okrem vel'kosti sídla a príjmu vytvorila binárne znaky (dummy premenné). Vel'kost' sídla je v dotazníku meraná na devät'stupňovej škále a mesačný príjem domácnosti na desat'- 
stupňovej škále. Tieto premenné vstupujú do analýzy nezmenené. $Z$ dôvodu l'ahšej interpretovatel'nosti výsledkov analýzy som sa škálu spoločenskej dôvery rozhodla otočit' tak, aby korešpondovala so škálou závislej premennej, na ktorej najnižšia hodnota vyjadruje najnižšiu spokojnost' a najvyššia hodnota najvyššiu spokojnost' so životom. Podl'a podobnej logiky sú kódované aj ostatné indikátory sociálneho kapitálu.

Tabul'ka. č. 2: Lineárna regresia spokojnosti so životom $\mathbf{v}$ jednotlivých vlnách Výskumu európskych hodnôt

\begin{tabular}{|c|c|c|c|c|}
\hline \multirow{2}{*}{$\begin{array}{l}\text { Závislá premenná } \\
\text { Vlna }\end{array}$} & \multicolumn{4}{|c|}{ Spokojnost' so životom } \\
\hline & 1991 & 1999 & 2008 & 2017 \\
\hline$r^{2}$ & 0,071 & 0,108 & 0,091 & 0,192 \\
\hline \multirow[t]{2}{*}{ Počet pozorovaní } & 1137 & 1327 & 1509 & 1435 \\
\hline & \multicolumn{4}{|c|}{ Neštandardizovaný B koeficient (štandardná chyba) } \\
\hline Konštanta & $8,210(0,586)^{* * *}$ & $5.675(0.587)^{* * *}$ & $6,872(0,628)^{* * *}$ & $6,425(0,448)^{* * *}$ \\
\hline Pohlavie - muž & $-0,372(0,168)^{*}$ & $-0,074(0,149)$ & $-0,027(0,154)$ & $-0,402(0,120)^{* *}$ \\
\hline \multicolumn{5}{|l|}{$\begin{array}{l}\text { Pohlavie - žena (ref. } \\
\text { kat.) }\end{array}$} \\
\hline Vek $25-34$ & $-0,196(0,279)$ & $-0,002(0,290)$ & $-0,034(0,310)$ & $-0,162(0,224)$ \\
\hline Vek $35-44$ & $-0,952(0,296)^{* * *}$ & $-0,173(0,306)$ & $-0,343(0,321)$ & $-0,720(0,245)^{* *}$ \\
\hline Vek $45-54$ & $-0,890(0,321)^{* *}$ & $-0,314(0,312)$ & $-0,450(0,340)$ & $-1,156(0,255) * * *$ \\
\hline Vek $55-64$ & $-0,023(0,334)$ & $-0,299(0,353)$ & $-0,549(0,348)$ & $-0,882(0,260) * * *$ \\
\hline Vek 64+ & $-0,118(0,350)$ & $-0,379(0,382)$ & $-0,807(0,382)^{*}$ & $-0,922(0,274)^{* * *}$ \\
\hline \multicolumn{5}{|l|}{ Vek do 25 (ref. kat.) } \\
\hline $\begin{array}{l}\text { Vzdelanie - SŠ bez } \\
\text { maturity }\end{array}$ & $-0,090(0,233)$ & $0,249(0,202)$ & $-0,114(0,217)$ & $0,538(0,225)^{*}$ \\
\hline $\begin{array}{l}\text { Vzdelanie }-\mathrm{SS} \\
\text { s maturitou }\end{array}$ & $-0,040(0,252)$ & $0,522(0,218)^{*}$ & $0,099(0,223)$ & $0,666(0,219)^{* *}$ \\
\hline Vzdelanie - VŠ & $0,451(0,348)$ & $0,839(0,291)^{* *}$ & $0,229(0,308)$ & $0,836(0,259) * * *$ \\
\hline \multicolumn{5}{|c|}{ Vzdelanie - ZŠ (ref. kat.) } \\
\hline Slobodný & $-0,613(0,246)^{* *}$ & $-0,177(0,229)$ & $-0,614(0,232)^{* *}$ & $-0,461(0,165)^{* *}$ \\
\hline $\begin{array}{l}\text { Rozvedený alebo } \\
\text { oddelený }\end{array}$ & $-0,867(0,447)^{*}$ & $-1,152(0,301)^{* * *}$ & $-0,742(0,289)^{* *}$ & $-0,479(0,290)^{*}$ \\
\hline Ovdovený & $-0,199(0,332)$ & $0,391(0,321)$ & $-0,256(0,266)$ & $-0,473(0,234)^{*}$ \\
\hline \multicolumn{5}{|c|}{ Ženatý/vydatá (ref. kat.) } \\
\hline Vel'kost' obce & $-0,103(0,042)^{* *}$ & $-0,076(0,034)^{*}$ & $0,083(0,036)^{*}$ & $0,070(0,028)^{* *}$ \\
\hline Príjem domácnosti & $0,155(0,071)^{*}$ & $0,279(0,059)^{* * *}$ & $0,236(0,062) * * *$ & $0,209(0,048) * * *$ \\
\hline Členstvo v združení & $0,275(0,162)$ & $0,023(0,150)$ & $0,194(0,175)$ & $0,149(0,134)$ \\
\hline Spoločenská dôvera & $0,614(0,195)^{* *}$ & $0,465(0,194)^{*}$ & $0,220(0,217)$ & $0,039(0,138)$ \\
\hline $\begin{array}{l}\text { Dôvera k štátnym } \\
\text { inštitúciám }\end{array}$ & $0,089(0,037)^{*}$ & $0,113(0,035)^{* * *}$ & $0,070(0,032)^{*}$ & $0,136(0,025)^{* * *}$ \\
\hline $\begin{array}{l}\text { Ospravedlnitel'nost' } \\
\text { konania }\end{array}$ & $-0,086(0,037)$ & $0,023(0,043)$ & $-0,007(0,043)$ & $-0,068(0,031)^{*}$ \\
\hline
\end{tabular}


Ako som už uviedla, mojím ciel'om je tiež porovnat' štyri vlny výskumu EVS na Slovensku, ktoré budú v analýze reprezentovat' osobitné modely. Počet respondentov sa $\mathrm{v}$ jednotlivých vlnách pohyboval od $1135 \mathrm{v}$ roku 1991 až po 1509 v roku 2008. Dátové súbory výskumu EVS sú na výskumné účely vol’ne dostupné v Slovenskom archíve sociálnych dát.

\section{Výsledky}

Analýza determinantov osobnej pohody v štyroch vlnách EVS na Slovensku poukázala $\mathrm{v}$ prvom rade na to, že nie všetky výsledky sú konzistentné v čase.

Pokial' ide o jednotlivé dimenzie sociálneho kapitálu, s určitost'ou môžem vyslovit' iba to, že dôvera $\mathrm{k}$ štátnym inštitúciám je konzistentne pozitívnym a signifikantným prediktorom osobnej pohody vo všetkých sledovaných vlnách. Tento výsledok je nezávislý od toho, či počítame s pôvodnými štvorstupňovými škálami dôvery $\mathrm{k}$ inštitúciám alebo s prekódovanými dvojstupňovými škálami, ktoré vstupovali do modelov uvedených v tabulke. Moje zistenie korešponduje so zisteniami Hudsona (2006), ktorý analyzoval vztah medzi inštitucionálnou dôverou a pohodou v západnej Európe. Hudson vo svojej štúdii taktiež konštatuje endogénnu povahu inštitucionálnej dôvery, pretože podl'a neho táto dôvera vyplýva z výkonu a efektívnosti inštitúcií. Ak je teda dôvera $\mathrm{k}$ inštitúciám aspoň čiastočne založená na ich výkone a súčasne dôvera k inštitúciám zvyšuje osobnú pohodu, tak z toho podla Hudsona vyplýva, že výkon inštitúcií vplýva na pohodu (Hudson 2006). Hypotézu o dôvere k inštitúciám založenej na ich výkone okrem Hudsona potvrdzujú aj Klobucký a Mrva (2019) vo svojej štúdii, v ktorej pracujú s totožnými dátami ako tento článok. Na základe týchto zistení teda môžeme súhlasit' so závermi Freya a Stutzera (2002), ktorí hovoria, že výkon inštitúcií má priamy vplyv aj na kvalitu nášho života a na osobnú pohodu.

Spoločenská dôvera, ktorá spolu s inštitucionálnou dôverou tvorí jednu z troch dimenzií sociálneho kapitálu, mala pozitívny vplyv na spokojnost' so životom vo všetkých štyroch vlnách, avšak tento vzt’ah bol štatisticky signifikantný iba v rokoch 1991 a 1999. Vplyv ostatných dimenzií sociálneho kapitálu, teda sociálnych sietí (ktoré boli merané cez členstvo v združeniach) a sociálnych noriem (merané cez ospravedlnitel'nost' konania), nebol počas jednotlivých vín výskumu konzistentný a ani signifikantný, respektíve bol len malý.

Pokial' ide o demografické znaky, ženy sú vo všetkých vlnách spokojnejšie ako muži, tento rozdiel je však signifikantný iba v prvej a poslednej sledovanej vlne. Ako to opisujú Batz a Tay (2018) vo svojej metaanalýze, zistenia týkajúce sa rodových rozdielov v osobnej pohode nie sú konzistentné, a preto sú možné rozdielne vysvetlenia. Vek ako determinujúci faktor spokojnosti so životom sa nejaví ako signifikantný v každej vlne rovnako, avšak trend ukazuje, že vekom sa znižuje spokojnost'. Dosiahnutie úplného stredoškolského 
alebo vysokoškolského vzdelania výrazne zvyšuje spokojnost' so životom najmä v poslednej vlne. O pozitívnom vzt’ahu medzi vzdelaním a osobnou pohodou referujú mnohé štúdie (napr. Easterlin 2001; Blanchflower - Oswald 2004), väčšina z nich však tento vzt'ah príliš nevysvetl'uje (Kristoffersen 2018). Tí, čo sa pokúsili poskytnút' vysvetlenie, väčšinou zdôrazňujú úlohu vzdelania ako mediátora. Napríklad Powdthavee et al. (2015) na austrálskej vzorke dokazujú, že vzdelanie nezvyšuje spokojnost' so životom samo osebe, ale prostredníctvom zdravia a príjmu.

Ludia žijúci v manželstve vykazovali aj v našich vzorkách vyššiu spokojnost' ako slobodní, rozvedení alebo ovdovení respondenti, čo je v súlade so zisteniami väčšiny výskumov (pozri napr. Helliwell - Putnam 2004; Grover Helliwell 2019). Frey a Stutzer (2002) to vysvetl'ujú tým, že manželstvo znižuje pocit osamelosti a tiež znamená podporu, vd’aka ktorej sa jednotlivec l'ahšie vyrovnáva s problémami. Na schopnost' vyrovnat' sa s problémami má bezpochyby vplyv aj finančná situácia jednotlivca, ktorá sa javí ako pozitívny a signifikantný prediktor osobnej pohody vo všetkých sledovaných vlnách. Zistenie, že vyšší príjem znamená vyššiu spokojnost' so životom, opisuje mnoho štúdií, na dátach zo Slovenska napríklad Želinský et al. (2018). Rözer a Kraaykamp (2013) však vo svojej analýze 85 krajín sveta upozorňujú aj na prepojenia medzi inštitucionálnou a spoločenskou dôverou, príjmom a osobnou pohodou. Podl'a ich zistení l’udia, ktorí v Európe žijú v krajinách, kde sú vel'ké príjmové nerovnosti, prejavujú nižšiu mieru spokojnosti so životom, kým l'udia, ktorí žijú v krajinách, kde je vysoká miera dôvery k inštitúciám, pocitujú aj vyššiu osobnú pohodu. Medzi spoločenskou dôverou a osobnou pohodou, podobne ako ja, nenašli signifikantný vzt’ah (Rözer - Kraaykamp 2013).

\section{Záver}

Analýza štyroch vĺn Výskumu európskych hodnôt na Slovensku preukázala, že jednotlivé dimenzie sociálneho kapitálu neprispievajú k pocitu spokojnosti so životom rovnako. Dimenzia dôvery sa z pohl'adu osobnej pohody ukázala ako najdôležitejšia. Dôvera k štátnym inštitúciám bola aj jedinou konzistentne významnou premennou vo všetkých štyroch vlnách výskumu. $\mathrm{V}$ tomto prípade sa tiež dá diskutovat' o smere kauzálneho vzt'ahu (vieme si predstavit' aj možnost', že spokojnejší l'udia prenášajú svoju spokojnost' aj na inštitúcie, ktorým potom viac dôverujú), s určitost'ou však môžeme tvrdit', že spokojnost' so životom je v pozitívnom vzt’ahu s tým, ako vnímame výkony štátnych inštitúcií.

Treba tiež dodat', že výber indikátorov jednotlivých dimenzií sociálneho kapitálu bol obmedzený dostupnými dátami, preto jednotlivé dimenzie sociálneho kapitálu neboli indikátormi rovnako pokryté. Najviac nasýtená bola dimenzia dôvery meraná prostredníctvom spoločenskej dôvery a indexu dôvery k štátnym inštitúciám. 
Z kontextuálnych premenných sú najkonzistentnejšie výsledky týkajúce sa príjmu, ktoré ukazujú pozitívny vplyv príjmu domácnosti na spokojnost' so životom. Nevysvetlená variancia modelov je však 80 až 90 \%, z čoho vyplýva, že treba preskúmat' ešte vel'a d'alších skutočností, ktoré vplývajú na osobnú pohodu na Slovensku.

Marianna Mrva je doktorandkou na Sociologickom ústave SAV a externou spolupracovničkou Fórum inštitútu pre výskum menšin. Vo svojej dizertačnej práci sa venuje fenoménu spoločenskej dôvery na Slovensku. Na Sociologickom ústave sa podiel'a na riešeni výskumných úloh spojených s medzinárodným Výskumom európskych hodnôt.

LITERATÚRA

BANFIELD, E. C., 1967: Moral Basis of a Backward Society. New York: The Free Press.

BARTOLINI, S. - BILANCINI, E. - PUGNO, M., 2008: Did the Decline in Social Capital Depress Americans' Happiness? Department of Economics University of Siena 540. Department of Economics, University of Siena.

BATZ, C. - TAY, L., 2018: Gender Differences in Subjective Well-Being. In: Diener, E. - Oishi, S. - Tay, L. (eds.): Handbook of well-being. Salt Lake City: UT: DEF Publishers.

BECKER, G. S., 1962: Investment in Human Capital: A Theoretical Analysis. Journal of Political Economy 70, č. 5, s. 9-49. https://doi.org/10.1086/258724

BECKER, G. S., 1964: Human Capital. New York: Columbia University Press.

BJØRNSKOV, C., 2003: The Happy Few: Cross-Country Evidence on Social Capital and Life Satisfaction. Kyklos 56, č. 1, s. 3-16. https://doi.org/10.1111/14676435.00207

BJØRNSKOV, C., 2008: Social capital and happiness in the United States. Applied Research in Quality of Life 3, č. 1, s. 43-62. https://doi.org/10.1007/s11482-0089046-6

BLANCHFLOWER, D. G. - OSWALD, A. J., 2004: Well-Being Over Time in Britain and the USA. Journal of Public Economics 88, č. 7-8, s. 1359-1386. https://doi.org/10.1016/S0047-2727(02)00168-8

BOURDIEU, P., 1986: The Forms of Capital. In: Richardson, J. (ed.): Handbook of Theory and Research for the Sociology of Education. Westport. CT: Greenwood.

BOURDIEU, P., 1977: Outline of a Therory of Practice. Cambridge: Cambridge University Press.

COLEMAN, J. S., 1988: Social Capital in the Creation of Human Capital. American Journal of Sociology 94, s. 95-120. https://doi.org/10.1086/228943

DIENER, E. - OISHI, S. - LUCAS, E. R., 2009: Subjective Well-Being: The Science of Happiness and Life Satisfaction. In: Lopez, S. J. - Snyder, C. R. (eds.): The Oxford Handbook of Positive Psychology. New York: Oxford University Press. http://dx.doi.org/10.1093/oxfordhb/9780195187243.013.0017 
DIENER, E. - SUH, M. E. - LUCAS, E. R. - SMITH, L. H., 1999: Subjective WellBeing: Three Decades of Progress. Psychological Bulletin 125, č. 2, s. 276-302. https://doi.org/10.1037/0033-2909.125.2.276

DIENER, E. - SUH, M. E. - OISHI, S., 1997: Recent findings on subjective wellbeing. Indian Journal of Clinical Psychology 24, č. 1, s. 25-41.

DOLAN, P. - KUDRNA, L. - TESTONI, S., 2017: Definition and Measures of Subjective Well-being. Centre for Economic Performance (Discussion paper 3), s. $1-9$.

DRENTEA, P. - MOREN-CROSS, J. L., 2005: Social Capital and Social Support on the Web: The Case of an Internet Mother Site. Sociology of Health and Illness 27, č. 7, s. 920-943. https://doi.org/10.1111/j.1467-9566.2005.00464.x

EASTERLIN, R. A., 1974: Does Economic Growth Improve the Human Lot? Some Empirical Evidence. In: David, A. P. - Reder, W. M. (eds.): Nations and Households in Economic Growth. Essays in Honor of Moses Abramovitz. London: Academic Press. https://doi.org/10.1016/B978-0-12-205050-3.50008-7

EASTERLIN, R. A. - MCVEY, A. L. - SWITEK, M. - SAWANGFA, O. - SMITH ZWEIG, J., 2010: The Happiness - Income Paradox Revisited. Proceedings of the National Academy of Sciences of the United States of America 107, č. 52, s. 2246322468. https://doi.org/10.1073/pnas.1015962107

EASTERLIN, R., 2001: Income and Happiness: Towards a Unified Theory. The Economic Journal 111, č. 473, s. 465-484. https://doi.org/10.1111/1468-0297.00646

ELGAR, F. J. et al., 2011: Social Capital, Health and Life Satisfaction in 50 Countries. $\begin{array}{lllll}\text { Health and } \quad \text { Place } 17, \quad 5, \quad \text { s. } & 1044-1053 .\end{array}$ https://doi.org/10.1016/j.healthplace.2011.06.010

EVS Bibliograhy $\mathrm{ku}$ dňu 16.3.2020: https://europeanvaluesstudy.eu/educationdissemination-publications/evs-publications/publications/

FREY, B. S. - STUTZER, A., 2002: Happiness and Economics: How the Economy and Institutions Affect Well-Being. Princeton: Princeton University Press. doi:10.2307/j.ctt7rm1k

GROVER, S. - HELLIWELL, J. F., 2019: How's Life at Home? New Evidence on Marriage and the Set Point for Happiness. Journal of Happiness Studies 20, č. 2, s. 373-390. https://doi.org/10.1007/s10902-017-9941-3

HAYBRON, D. M., 2008: Philosophy and the Science of Subjective Well-Being. In: Eid, M. - Larsen. R. J. (eds): The science of subjective well-being. New York: Guilford Press.

HELLIWELL, J. F., 2002: How's Life? Combining Individual and National Variables. NBER Working Paper Series. doi:10.3386/w9065

HELliWElL, J. F. - PUTNAM, R. D., 2004: The Social Context of Well-Being. Philosophical Transactions of the Royal Society of London. Series B, Biological Sciences 359, č. 1449, s. 1435-1446. doi:10.1098/rstb.2004.1522

HELLIWELL, J. F. - LAYARD, R. - SACHS, D. J. - DE NEVE, J.-E., 2020: World Happiness Report. OECD. Dostupné na https://worldhappiness.report/ ku dňu 24.3.2020

HOMANS, G. C., 1961: Social Behavior: Its Elementary Forms. Oxford: Harcourt, Brace. 
HUDSON, J., 2006: Institutional Trust and Subjective Well-Being across the EU. Kyklos 59, č. 1, s. 43-62. https://doi.org/10.1111/j.1467-6435.2006.00319.x

ISHAM, J. - KELLY, T. - RAMASWAMY, S. (eds.), 2002: Social Capital and Economic Development: Well-Being in Developing Countries. Cheltenham: Edward Elgar.

JACOBS, J., 1961: The Death and Life of Great American Cities. New York: Random House.

KELLER, J., 2010: Nejistota a důvěra aneb k čemu je modernitě dobrá tradice. Praha: SLON.

KLOBUCKÝ, R. - MRVA, M., 2019: Vývoj spoločenskej dôvery. In: Rabušic, L. Kusá, Z. - Manea, Ch. B. - Strapcová, K. (eds.): Odděleně spolu? Česko a Slovensko optikou vývoje hodnot po roce 1991. Bratislava: Slovart.

KRISTOFFERSEN, I., 2018: Great Expectations: Education and Subjective WellBeing. Journal of Economic Psychology 66, s. 64-78. doi: 10.1016/j.joep.2018.04.005

LIN, N., 2007: A Network Theory of Social Capital. In: Castiglione, D. - van Deth, J. - Wolleb, G. (eds.): The Handbook of Social Capital. New York: Oxford University Press.

LOURY, G., 1977: A Dynamic Theory of Racial Income Differences. In: Wallace, A. P. - Le Mund, E. (eds): Women. Minorities, and Employment Discrimination. Lexington: Lexington Books.

LYUBOMIRSKY, S. L. - KING, L. - DIENER, E., 2005: The Benefits of Frequent Positive Affect: Does Happiness Lead to Success? Psychological Bulletin 131, č. 6, s. 803-855. https://doi.org/10.1037/0033-2909.131.6.803

LUHMANN, M. - SCHIMMACK, U. - EID, M., 2011: Stability and Variability in the Relationship between Subjective Well-Being and Income. Journal of Research in Personality 45, č. 2, s. 186-197. https://doi.org/10.1016/j.jrp.2011.01.004

MADDUX, E. J., 2018: Subjective Well-Being and Life Satisfaction: An Introduction to Conceptions, Theories, and Measures. In: Maddux, E. J. (ed.): Subjective WellBeing and Life Satisfaction. London: Routledge.

NGAMABA, K. H. - PANAGIOTI, M. - ARMiTAGE, C. J., 2017: How Strongly Related are Health Status and Subjective Well-Being? Systematic Review and Meta-Analysis. European Journal of Public Health 27, č. 5, s. 879-885. https://doi.org/10.1093/eurpub/ckx081

NORRIS, P., 2002: The Bridging and Bonding Role of Online Communities. Harvard International Journal of Press/Politics 7, č. 3, s. 3-13.

NORMAN, G., 2010: Likert Scales, Levels of Measurement and the "Laws" of Statistics. Advances in Health Sciences Education 15, č. 5, s. 625-632. https://doi.org/10.1007/s10459-010-9222-y

OLSON, M., 1982: The Rise and Decline of Nations : Economic growth, Stagflation, and Social Rigidities. New Haven: Yale University Press.

OSTRON, E. - AHN, T. K., 2009: The Meaning of Social Capital and Its Link to Collective Action. In: Svedsen, G. T. - Svedsen, H. L. G. (eds): Handbook of social capital. The troika of sociology, political science and economics. Cheltenham: Edward Elgar Publishing. 
PORTELA, M. - NEIRA, I. - SALINAS-JIMÉNEZ, M. M., 2013: Social Capital and Subjective Wellbeing in Europe: A New Approach on Social Capital. Social Indicators Research 114, č. 2, s. 493-511. https://doi.org/10.1007/s11205-012-0158$\mathrm{X}$

POWDTHAVEE, N. - LEKFUANGFU, W. N. - WOODEN, M., 2015: What's the Good of Education on our Overall Quality of Life? A Simultaneous Equation Model of Education and Life Satisfaction for Australia. Journal of Behavioral and Experimental Economics 54, s. 10-21. https://doi.org/10.1016/j.socec.2014.11.002

PUNTCHER, S. - HAUSER, CH. - WALDE, J. - TAPPEINER, G., 2014: The Impact of Social Capital on Subjective Well-Being: A Regional Perspective. Journal of Happiness Studies 16, č. 5, s. 1231-1246. https://doi.org/10.1007/s10902-014-9555$\mathrm{y}$

PUTNAM, R. D., 2001: Bowling Alone: The Collapse and Revival of American Community. New York: Simon \& Schuster Paperbacks.

PUTNAM, R. D. - LEONARDI, R. - NONETTI, R. Y., 1994: Making Democracy Work. Princeton: Princeton University Press.

RÖZER, J. - KRAAYKAMP, G., 2013: Income Inequality and Subjective Well-Being: A Cross-National Study on the Conditional Effects of Individual and National Characteristics. Social Indicators Research 113, č. 3, s. 1009-1023. https://doi.org/10.1007/s11205-012-0124-7

RUMAN, J., 2013: „Sociálny kapitál“: kritická perspektíva a nachádzanie optimálnej signifikancie. Studia Politica Slovaca 6, č. 1, s. 24-40.

SARRACINO, F., 2010: Social Capital and Subjective Well-Being Trends: Comparing 11 Western European Countries. Journal of Socio-Economics 39, č. 4, s. 482-517. https://doi.org/10.1016/j.socec.2009.10.010

SARRACINO, F., 2013: Richer in Money, Poorer in Relationships and Unhappy? Time Series Comparisons of Social Capital and Well-Being in Luxembourg. Social Indicators Research 115, č. 2, s. 561-622. doi:10.1007/s11205-012-0223-5

SARRACINO, F. - MIKUCKA, M., 2016: Social Capital in Europe from 1990 to 2012: Trends and Convergence. Social Indicators Research 131, č. 1, s. 407-432. https://doi.org/10.1007/s11205-016-1255-z

SHAPIRO, A. - KEYES, C. L. M., 2008: Marital Status and Social Well-Being: Are the Married always better off? Social Indicators Research 88, č. 2, s. 329-346. https://doi.org/10.1007/s11205-007-9194-3

SMITH, C., 2014: Easterlin Paradox. In: Michalos, C. A. (ed.): Encyclopedia of Quality of Life and Well-Being Research. Springer Netherlands.

SCHULTZ, T. W., 1960: Capital Formation by Education. Journal of Political Economy 68, č. 6, s. 571-83.

SZRETER, S. - WOOLCOCK, M., 2004: Health by Association? Social Capital, Social Theory, and the Political Economy of Public Health. International Journal of Epidemiology 33, č. 4, s. 650-667. https://doi.org/10.1093/ije/dyh013 
van OORSCHOT, W. - FINSVEEN, E., 2009: The Welfare State and Social Capital Inequality European Societies 11, č. 2, s. 189-210.

https://doi.org/10.1080/14616690802155346

van OORSCHOT, W. - ARTS, W. - GELISSEN, J., 2006: Social Capital in Europe. Acta Sociologica 49, č. 2, s. 149-167. https://doi.org/10.1177/0001699306064770

VEENHOVEN, R., 1991: Is Happiness Relative? Social Indicators Research 24, s. 134. https://doi.org/10.1007/BF00292648

VEENHOVEN, R., 2008: Sociological Theories of Subjective Well-Being. In: Eid, M. - Larsen, J. R. (eds.): The science of subjective well-being. New York: Guilford Press.

VEENHOVEN, R. - KALMIJN, W., 2005: Inequality-Adjusted Happiness in Nations Egalitarianism and Utilitarianism Married in a New Index of Societal Performance. Journal of Happiness Studies 6, č. 4, s. 421-55. https://doi.org/10.1007/s10902-0058857-5

WELLMAN, B. - QUAN HAASE, A. - WITTE, J., 2001: Does the Internet Increase, Decrease, or Supplement Social Capital?: Social Networks, Participation, and Community Commitment. American Behavioral Scientist 45, č. 3, s. 436-455. https://doi.org/10.1177/00027640121957286

WILSON, W. R., 1967: Correlates of Avowed Happiness. Psychological Bulletin 67, č. 4, s. 294-306. https://doi.org/10.1037/h0024431

WVS publications ku dňu 16. 3. 2020: http://www.worldvaluessurvey.org/WVSPublicationsPapers.jsp

ŽELINSKÝ, T. - SOROKOVÁ, T. - PETRÍKOVÁ, D., 2018: Economic Characteristics and Subjective Well-Being. Sociológia 50, č. 3, s. 334-364. 